Vol. 1, No. 1, Juni 2020

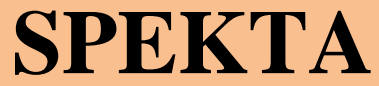

Jurnal Pengabdian Kepada Masyarakat : Teknologi dan Aplikasi

Journal homepage :

http://journal2.uad.ac.id/index.php/spekta

\title{
PERAN UKM DALAM MENSTABILKAN HARGA MASKER SEBAGAI BENTUK PENCEGAHAN PENYEBARAN COVID-19 DI BANDA ACEH
}

\author{
Rahmat Arfan ${ }^{1}$, Hamdani ${ }^{1, *}$, Desy Puspita ${ }^{1}$, Indra Akbar ${ }^{2}$, Geta ambartiasari ${ }^{3}$, Mirnawati ${ }^{2}$ \\ ${ }^{1}$ Program Studi Manajemen Keuangan Sektor Publik, Politeknik Kutaraja Banda Aceh, Jl. Syiah Kuala No.10, \\ Bandar Baru, Banda Aceh , Indonesia \\ ${ }^{2}$ Program Studi Administrasi Perkantoran, Politeknik Kutaraja Banda Aceh, Jl. Syiah Kuala No.10, Bandar Baru, \\ Banda Aceh, Indonesia \\ ${ }^{3}$ Program Studi Pengelolaan Perkebunan, Politeknik Indonesia Venezuela, Jl. Bandara Sultan Iskandar Muda, Cot \\ Suruy, Aceh Besar, Indonesia

\begin{tabular}{l}
\hline INFO ARTIKEL \\
\hline Riwayat artikel : \\
Diterima : Mei 2020 \\
Direvisi : Mei 2020 \\
Disetujui : Juni 2020 \\
\hline
\end{tabular} \\ Keywords: \\ SMES \\ Covid-19 \\ Masker \\ Healthy

\begin{abstract}
Community Service Activities (PkM) aim to help ease the burden on people affected by Covid-19 in Banda Aceh. This activity has resulted in a caring attitude towards people who need masks at affordable prices. Meanwhile, the price of masks has been influenced by market mechanisms. By empowering micro, small and medium enterprises (SMEs) to produce masks made of cloth, the availability of masks in the market has reduced scarcity so that prices are stable. The method of implementing this activity is direct application in the field
\end{abstract}

\section{PENDAHULUAN}

Pada bulan Desember 2019 dunia digemparkan dengan munculnya virus yang akhirnya diberi nama Corona Virus Disease 19 yang awal kemunculannya di Wuhan China (WANG and HE, 2020). Penyebaran virus ini sangatlah cepat sehingga di awal tahun 2020 virus ini telah masuk ke Indonesia, dengan penyebaran sampai Maret 2020 di Indonesia menyebabkan korban meninggal sebanyak 170 orang dan terus meningkat (Alodokter, 2020), diikuti dengan korban yang meninggal di Aceh sebanyak 1 orang dan 5 orang positif (BBC, 2020).

Akibat perkembangan yang sangat cepat dalam hitungan bulan virus ini telah menggemparkan dunia yang mana mengakibatkan pengaruh yang sangat besar terhadap banyak askpek, selain kesehatan aspek lain yang mempengaruhi ialah ekonomi, politik, sosial budaya dan pendidikan.

Di tingkat sosial budaya dan pendidikan banyak level pendidikan baik dari pendidikan dasar sampai pendidikan tinggi terpaksa untuk di ubah menjadi kelas secara daring mengingat perlunya menjaga jarak sosial yang diterapkan oleh Pemerintah

\footnotetext{
* Corresponding author.

E-mail address: hamdani.aceh@gmail.com

https://doi.org/10.12928/J.spekta.v1i1.2694
} 
Vol. 1, No. 1, Juni 2020

Indonesia, beberapa daerah seperti Aceh telah menerapkan pendidikan secara daring sampai dengan 28 Maret 2020 dan kemudian diperpanjang lagi berdasarkan surat Gubernur Nomor: 04/INSTR/2020 dengan kesimpulan pendidikan tanpa tatap muka dilanjutkan sampai tanggal 30 Mei 2020 (Fajri, 2020).

Dari segi politik banyak negara yang saat wabah ini merebak menutup pintu masuk untuk keluar masuk, banyak pesawat yang membatalkan penerbangan selama wabah ini dan banyak yang melarang masyarakatnya untuk tidak keluar dari negara maupun wilayahnya. Di Indonesia sendiri berdasarkan Peraturan Menteri Perhubungan Nomor: 25 tahun 2020 telah melarang masyarakat untuk melakukan mudik selama lebaran ini mengingat Indonesia sedang dilanda wabah (PERMENHUB, 2020). Kemudian secara khususnya Aceh juga mewajibkan masyarakat yang tiba dari wilayah wabah untuk melakukan karantina mandiri dan melaporkan kepada lembaga penanggulangan wabah di tiap desa atau gampongnya.

Dari segi ekonomi dampak yang dirasakan hampir pada setiap level bisnis, baik dari ekonomi rakyat seperti UKM dan ekonomi makro dengan di tandai penurunan nilai tukar rupiah dengan US dollar. Secara tidak langsung pengaruh ekonomi meningkatkan harga di Indonesia secara umum dan Aceh secara khususnya (Kiky, 2020)

Dari banyaknya aspek yang mempengaruhi diatas secara simultan mempengauhi nilai beli yang meningkat drastis atau Panic Buying yang menurunkan persediaan stok seperti alat pelindung diri (APD) rumah sakit, vitamin $C$, hand sanitizer dan masker, akibat dari penurunan persediaan stok diatas mempengaruhi harga yang meningkat (Budiyanti, 2020). Penurunan persediaan stok alat kesehatan tersebut di atas bertolak belakang dengan kebutuhan rumah sakit yang sangat tinggi sehinga rentannya penyebaran kepada petugas kesehatan lebih tinggi dari pada masyarakat umum lainnya.(Dai, 2020)

Sehingga berdasarkan dari rasa prihatin diatas perlu dilaksanakan pengabdian masyarakat dengan menyasarkan kebutuhan masker jenis kain di masyarakat agar kebutuhan masker bedah bagi rumah sakit tidak terganggu dan pada akhirnya berharap penurunan harga sehingga dapat menjadi prioritas pembelian oleh rumah sakit agar penyebaran tidak menyasar langsung kepada pekerja medis di rumah sakit

\section{METODE PELAKSANAAN}

Kegiatan Pengabdian kepada Masyarakat ini dilaksanakan dengan metode langsung di lapangan. Metode terapan yang dipilih karena relevan dengan kebutuhan masyarakat saat ini. Berikut logika berpikir metode pelaksanaan disajikan pada gambar 1 dibawah ini:

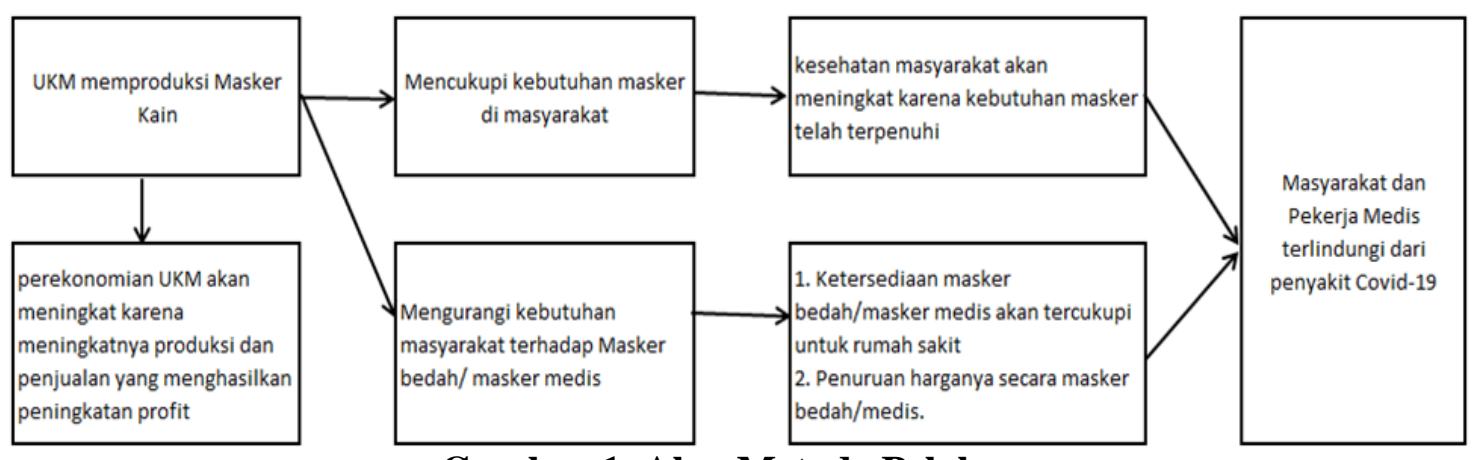

Gambar 1. Alur Metode Pelaksanaan 
Vol. 1, No. 1, Juni 2020

\section{HASIL DAN PEMBAHASAN}

Kegiatan dilaksanakan selama satu hari di Kantor Geuchik Gampong Geuceu Komplek, dengan dihadiri 13 orang peserta. Kegiatan berisikan penjelasan mengenai Peran UKM dalam menciptakan masker sebagai alternatif terhadap kebutuhan masker bedah/masker medis di masyarakat. Kegiatan diakhiri dengan pembagian masker sebanyak 125 masker kepada Keuchik Gampong Geuceu Komplek sebagai bukti nyata dalam memenuhi kebutuhan masker bagi masyarakat Gampong Geuceu Komplek secara khususnya.

Kegiatan dimulai dengan penjelasan kegiatan secara umum dan peran UKM dalam sektor ekonomi. Dengan fokus sektor ekonomi mikro yang berpusat di gampong atau lembaga pelatihan lainnya. Terbentuknya UKM yang mandiri akan membuat perubahan pendapatan secara khusus terhadap pelaku usaha dan pemenuhan kebutuhan dari sisi masyarkat umum serta membantu pemerintah sebagai ekonomi makro dalam menyeimbangkan kebutuhan dan permintaan masyarakat.(Dwi Mardhia, Neri Kautsari, Lalu Ilham Syaputra, Wahyu Ramdhani, 2020)

Pemilihan dua pelaku usaha kecil menengah (UKM) dari Ibu Sur di Peukan Bada Aceh Besar dan "Beuna Raseuki" beralamat di Darussalam Banda Aceh bermaksud untuk mendukung UKM dari dua wilayah dengan peroduk yang sama namun qualitas serta bahan yang berbeda, sehingga dapat menjadi perbandingan bahwa banyak bahan yang dapat digunakan sebagai innovasi terhadap kebutuhan masker di masyarakat. Inovasi merupakan yang yang mutlak yang harus di ciptakan untuk saat ini mengingat kebutuhan akan masker sangat tinggi serta persediaan di masyarakat sangat sulit didapatkan. Hal ini berdampak kepada harga yang sangat tinggi.

Harga tinggi terhadap masker dapat di tekan dengan munculnya inovasi tertentu seperti munculnya masker kain yang diciptakan terhadap tingginya permintaan masker bedah/masker medis sehingga kebutuhan akan masker di masyarakat tidak mengganggu akan kebutuhan masker di rumah sakit karena alternatif masker kain yang diciptakan oleh UKM.

\section{KESIMPULAN}

Pengaruh merebaknya wabah Covid-19 dari sisi kesehatan secara berlanjut berdampak langsung kepada sosial masyarakat dan perekonomian. Semakin tinggi keperluan akan masker dan hand sanitizer di masyarakat menjadi kesempatan beberapa oknum dalam mengambil kesempatan keuntungan lebih, sehingga mempengaruhi kebutuhan dan stok bagi rumah sakit. Sangat banyak rumah sakit yang bahkan sudah kehabisan stok dan memaksa para medis bekerja tanpa pengamanan yang layak yang seharusnya merekalah yang lebih layak untuk kepastian keselamatan mengingat dokter dan perawatlah yang menghadapi pasien yang positif Covid-19. Merasa prihatin dan perlu diperhatikan maka perlu di bentuk solusi terhadap masalah ini, yang mana menyelesaikan banyak kendala secara sekaligus baik dari sisi sosial, ekonomi dan kesehatan.

Guna mendukung perencanaan penyelesaian sosial ekonomi dan kesehatan tersebut sasaran yang dituju ialah pemutusan kebutuhan masker bedah/masker kesehatan di masyarakat dengan menggantikan masker jenis tersebut kepada masker kain yang diproduksi oleh UKM masyarakat. Pada penyelesaian secara ekonomi produk yang digunakan ialah produk yang di buat dari dua UKM yang Ibu Sur di Peukan Bada Aceh Besar dan Beuna Raseuki di Darussalam, pemilihan UKM lokal bertujuan meningkatkan produksi mereka dan meningkatkan nilai jual sehingga profit yang didapatkan meningkatkan taraf ekonomi UKM tersebut 
Vol. 1, No. 1, Juni 2020

\section{UCAPAN TERIMA KASIH}

Ucapan terima kasih kami sampaikan kepada segenap kolega dan para Dosen Politeknik Kutaraja Banda Aceh yang telah mendukung dan membantu terlaksananya kegiatan Pengabdian kepada Masyarakat (PKM) ini dengan baik guna merespon kebutuhan masyarakat terhadap masker untuk melindungi diri dari ancaman penularan Covid-19. Begitu pula terima kasih tak terhingga kepada perangkat gampong (Desa) Geuceu Komplek mulai dari Kepala Desa hingga ketua lorong yang telah memberikan kesempatan, dukungan moril dan materil selama pelaksanaan kegiatan ini

\section{DAFTAR PUSTAKA}

Budiyanti, E. (2020) 'Dampak Virus Corona Terhadap Sektor Perdagangan Dan Pariwisata Indonesia', Kajian Bidang Ekonomi Dan Kebijakan Publik.

Dai, N. F. (2020) 'Stigma Masyarakat terhadap Pandemi Covid-19', Prosiding Seminar Nasional Problematika Sosial Pandemi Covid-19: Membangun Optimisme di Tengah Pandemi Covid-19.

Dwi Mardhia, Neri Kautsari, Lalu Ilham Syaputra, Wahyu Ramdhani, C. O. R. (2020) 'Penerapan Protokol Kesehatan Dan Dampak Covid-19 Terhadap Harga Komoditas Perikanan Dan Aktivitas Penangkapan', Indonesia journal of applied science and technology. doi: 10.1017/CBO9781107415324.004.

Kiky, A. (2020) 'Manajemen Resiko terhadap Black Swan Event Maret 2020 di Indonesia. Studi Kasus Efek Covid-19 Terhadap Pasar Modal Indonesia', Jurnal Bina Manajemen.

WANG, Y. and HE, Y. (2020) 'Opinions on the corona virus disease 2019', Chongqing Medicine.

Alodokter. (2020). Virus Corona. Alodokter.Com.

BBC. (2020). Virus corona: Peta dan infografis terkait pasien terinfeksi, meninggal dan sembuh di Indonesia dan dunia. $B B C$.

PERMENHUB (2020, 23 April) Peraturan Kementrian Perhubungan tentang Pengendalian selama Masa Mudik idul fitru tahun 1441 hijiriah dalam rangka pencegahan penyebaran Corona Virus Desease 2019 (Covid-19), Retrieved from http://jdih.dephub.go.id/assets/uudocs/permen/2020/PM_25_TAHUN_2020.pdf.

Fajri, R. (2020) Pemerintah Aceh Perpanjang Libur Sekolah Retrieved from https://www.ajnn.net/news/pemerintah-aceh-perpanjang-libur-sekolah/index.html 